\title{
PHOTODYNAMIC INACTIVATION OF RUBELLA VIRUS
}

\author{
J. C. BOOTH* AND H. STERN \\ Department of Virology, St George's Hospital Medical School, London
}

SINCE it is not yet certain that attenuated vaccine strains of rubella virus are devoid of teratogenic activity, a suitably inactivated vaccine might be preferable for use in pregnant women, particularly during epidemic periods. Attempts to prepare such vaccines by inactivating the virus, grown in primary African green monkey kidney cells, with formalin or ethylene oxide have met with varying success (Sever, Schiff and Huebner, 1963; Frankel, 1964; Meyer and Parkman, 1967; Hilleman et al., 1968). On the other hand, concentrated preparations of virus, grown in continuous baby-hamster kidney (BHK21) cells and rendered non-infectious by combined treatment with ultraviolet light and beta-propiolactone or by exposure to gamma-radiation, produced haemagglutination-inhibiting and neutralising antibodies in monkeys (see review by Beck, 1969).

We set out to investigate the effectiveness of photodynamic techniques for inactivating the infectivity of rubella virus. Enveloped viruses, in general, possess some inherent photosensitivity (Skinner and Bradish, 1954; Cutchins and Dayhuff, 1962; Wallis and Melnick, 1964; Nemo and Cutchins, 1966; Appleyard, 1967; Wallis, Trulock and Melnick, 1969). However, both enveloped and non-enveloped viruses are made highly photosensitive by treatment with various basic dyes (Hiatt, 1960; Wallis and Melnick, 1965). The resulting inactivation reaction, upon exposure to light, is selective for the viral genome (Chessin, 1960; Fukunaga et al. 1967) and infectivity is destroyed without significant loss of antigenicity (Frank and Foster, 1967; Fukunaga et al., Wallis, Scheiris and Melnick, 1967; Turner and Kaplan, 1968). For this reason, photodynamic inactivation with basic dyes has been used to prepare several experimental vaccines for virus infections other than rubella (Perdrau and Todd, 1933 $a$ and $b$; Dempsey and Meyer, 1934; Turner and Kaplan, 1965, 1968; Crawford and Dayhuff, 1968; Crawford, Dayhuff and White, 1968; Crawford, White and Dayhuff, 1968; Kaplan, 1969; Borgen and Espensen, 1970). Furthermore, Wallis et al. $(1963,1965,1967)$ have shown that the antigenic and immunogenic potency of photodynamically inactivated virus is superior to that of formalin-inactivated virus. The present report describes the intrinsic photosensitivity of rubella virus and its photodynamic inactivation catalysed by the basic dye proflavine.

Received 8 Mar. 1972; accepted 30 Mar. 1972.

* Present address: The Wellcome Laboratory, Pirbright, Surrey.

J. MED. MICROBIOL.,-VOL. 5 (1972) 


\section{MATERIALS AND METHODS}

Tissue cultures. Baby hamster kidney (BHK21) cells were grown in Eagle's medium BHK (Wellcome Reagents Ltd) containing 10 per cent. foetal calf serum, 10 per cent. tryptose phosphate broth, and penicillin and streptomycin. The maintenance medium was Eagle's medium BHK with 2 per cent. kaolin-treated foetal calf serum (Stewart et al., 1967) and the same antibiotics. Rabbit kidney (RK13) cells were grown in Parker's medium 199 containing 5 per cent. untreated foetal calf serum and antibiotics; for maintenance, the same medium was used with 2 per cent. foetal calf serum.

Virus. The Judith strain of rubella virus was passaged ten times in RK13 cell cultures, in this laboratory, before adaptation to BHK21 cells. Stock preparations of virus were made in BHK21 cells in $8 \mathrm{oz}$. medical flat bottles or $250 \mathrm{ml}$ Pyrex roller flasks. Monolayer cell sheets were freshly grown and the growth medium was replaced with a small amount of medium containing enough virus to give an inoculum dose of 0.1 TCD50 per cell. After 2 hours' incubation at $33^{\circ} \mathrm{C}$, maintenance medium was added, $12 \mathrm{ml}$ for bottles and $20 \mathrm{ml}$ for flasks, and incubation was continued at $33^{\circ} \mathrm{C}$. The cultures were refed with fresh maintenance medium after $24 \mathrm{hr}$, and on the $3 \mathrm{rd}$ day the supernatant fluids were removed, pooled, centrifuged at 4000 r.p.m. for $10 \mathrm{~min}$. to remove cellular debris, and stored in aliquots at $-90^{\circ} \mathrm{C}$. The infectivity and haemagglutinin titres, after thawing, were $10^{5.5} \mathrm{TCD} 50 \mathrm{per} \mathrm{ml}$ and 32 units per $0.025 \mathrm{ml}$ respectively; these did not alter significantly during the course of the investigations.

Proflavine. Stock solutions of proflavine hemisulphate (May and Baker Ltd), $100 \mu \mathrm{g}$ per

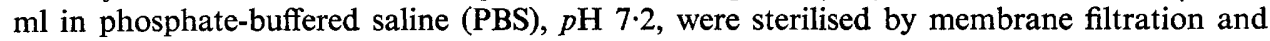
stored at $4^{\circ} \mathrm{C}$ in aluminium foil-wrapped bottles.

Photodynamic inactivation. This was carried out in a glass waterbath, the rear side of which was covered with aluminium foil to give an inner reflecting surface. Test tubes, $4 \times \frac{1}{2}$ in. $(100 \times 13 \mathrm{~mm})$, containing $4 \mathrm{ml}$ of virus suspension for inactivation were closed with rubber stoppers and attached vertically to the reflecting surface of the waterbath. The temperature of the water covering the tubes was kept at $20^{\circ} \pm 2^{\circ} \mathrm{C}$ throughout the experiment. The tubes were irradiated by incident light, from a Phillips Photolita No. 1 bulb operated at 240 volts A.C., passed horizontally through the front wall of the waterbath. The distance from the tubes to the lamp filament was $25 \mathrm{~cm}$. Measurements with a Gossen Lunasix 3 meter recorded an intensity of 4000 foot candles of incident light at the reflecting surface. Every experiment included "dark" controls which consisted of the virus suspension in tubes completely covered with aluminium foil; these were irradiated simultaneously with the test samples. Infectivity titrations were always done immediately after irradiation and the samples were stored at $-90^{\circ} \mathrm{C}$ until it was convenient to carry out haemagglutinin titrations. All experimental procedures, including the sampling and titrating of virus suspensions, were carried out under conditions of minimal room illumination. Previous tests had shown that this caused no detectable inactivation of virus, even when sensitised by direct mixing with as much as $10 \mu \mathrm{g}$ per $\mathrm{ml}$ of proflavine, over periods of at least $30 \mathrm{~min}$.

The inactivation of virus, after light irradiation, was measured as the logarithm $\left(\log _{10}\right)$ of the surviving fraction, the latter being taken as $\frac{N t}{N o}$, where $N t=$ the number of infective units of virus (TCD50) per $\mathrm{ml}$ after $t$ min. exposure to light and $N o=$ the number of infective units (TCD50) per $\mathrm{ml}$ before illumination. The inactivation rate constant $(k)$ was calculated from the formula:

$$
k=\frac{2.3 \times \log _{10} \frac{N o}{N t}}{t} \text { min. }^{-1}
$$

Infectivity titrations. Serial ten-fold dilutions of the virus suspension were inoculated, in $0.1 \mathrm{ml}$ amounts, into RK13 tubes, using three tubes per dilution. The tubes were incubated at $33^{\circ} \mathrm{C}$ in a roller drum. Cytopathic effects were read after 8 days, and infectivity titres (TCD50 per $\mathrm{ml}$ ) were calculated by the method of Reed and Muench (1938). 
Haemagglutinin $(H A)$ and haemagglutination-inhibition $(H I)$ tests. HA titrations and HI tests were done in disposable, plastic Microtitre plates, using 0.2 per cent. newborn chick erythrocytes, a sedimentation temperature of $4^{\circ} \mathrm{C}$ and dextrose-gelatin-veronal buffer supplemented with 0.4 per cent. bovine albumin as diluent (Stewart et al.). One HA unit was read as the highest dilution of virus suspension giving complete agglutination of the red cells. In $\mathrm{HI}$ tests, sera were absorbed with kaolin, inactivated at $56^{\circ} \mathrm{C}$ for $30 \mathrm{~min}$. and then preincubated with four HA units of antigen at $37^{\circ} \mathrm{C}$ for $15 \mathrm{~min}$. before adding the erythrocytes. Antibody titres were read as the reciprocal of the highest dilution of serum causing complete inhibition of agglutination.

Complement-fixing $(C F)$ antibody tests. Sera were inactivated at $56^{\circ} \mathrm{C}$ for $30 \mathrm{~min}$. and examined in microtitre plates as two-fold dilutions from 1 in 8 , using two units of antigen, two full units of complement and overnight fixation at $4^{\circ} \mathrm{C}$. The $\mathrm{CF}$ antigen was made from the supernatants of rubella-infected BHK21 cultures by concentrating them 100-fold by means of dialysis against polyethylene glycol (Schmidt et al., 1968). Antibody titres were read as the reciprocal of the highest dilution of virus giving $4+$ complement-fixation.

Cation-exchange resin. Dowex-50W, hydrogen form, 4 per cent. cross linked, dry mesh 50-100, cation-exchange resin (Sigma Chemical Co.) was washed repeatedly with five-fold concentrated PBS until the $p \mathrm{H}$ was stabilised at $7 \cdot 2$; at each wash the resin and buffer were mixed together for at least $10 \mathrm{~min}$. at room temperature. The resin $(50 \mathrm{~g})$ was then rinsed with 21 of single-strength PBS, and distributed in approximately 1 -ml quantities into $4 \times \frac{1}{2}$ in. Pyrex tubes containing $4.0 \mathrm{ml}$ of PBS. After sterilisation by steaming at $100^{\circ} \mathrm{C}$ for $30 \mathrm{~min}$., the tubes were closed with sterile rubber bungs and stored at $4^{\circ} \mathrm{C}$. The $p \mathrm{H}$ of the PBS in the resin tubes was still $7 \cdot 2$ after sterilisation. For use, the supernatant PBS was removed and replaced by $4 \mathrm{ml}$ of proflavine-treated virus suspension. The tubes were gently shaken for $1 \mathrm{~min}$. to allow any free proflavine in the virus suspension to adsorb to the resin. They were then centrifuged at 2000 r.p.m. for $10 \mathrm{~min}$. and the supernatants were harvested with Pasteur pipettes.

\section{RESULTS}

\section{Intrinsic photosensitivity of rubella virus}

Stock suspensions of rubella virus in maintenance medium, $p \mathrm{H} 7 \cdot 0-7 \cdot 2$, were exposed to light for $3 \mathrm{hr}$, and examined for loss of infectivity and HA activity at hourly intervals during the period of illumination. In two experiments, the infectivity titres decreased relatively slowly over the $3-\mathrm{hr}$ period, from $10^{5 \cdot 5}$ and $10^{5.75}$ TCD50 per $\mathrm{ml}$ to $10^{3.25}$ and $10^{3.5}$ TCD50 per $\mathrm{ml}$ respectively. The HA titres, on the other hand, were unaffected. The controls kept in the dark showed no change in either infectivity or HA levels. The rate of inactivation of infectivity was exponential (fig. 1) and the average inactivation rate constant $(k)$ was 0.03 min. ${ }^{-1}$.

Since serum is a known inhibitor of viral photoinactivation (Skinner and Bradish; Cutchins and Dayhuff; Appleyard), the experiments were repeated

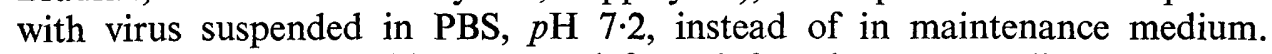
Supernatants were freshly harvested from infected BHK21 cell cultures and centrifuged at 40,000 r.p.m. for $2 \mathrm{hr}$. The virus deposit was resuspended in PBS to the original volume and exposed to light, as above. Infectivity was now destroyed more than twice as rapidly as in maintenance medium and was lost after 2 to $3 \mathrm{hr}$ (fig. 1). The rate of inactivation was exponential and the inactivation rate constant was $0.07 \mathrm{~min} .^{-1}$. HA activity was again unaltered, suggesting that the photoinactivation process did not involve the surface protein of the virus particle. The protective effect of serum was confirmed in further 
experiments in which serum was added to the PBS-suspensions of virus. The presence of serum reduced the amount of photoinactivation but did not abolish

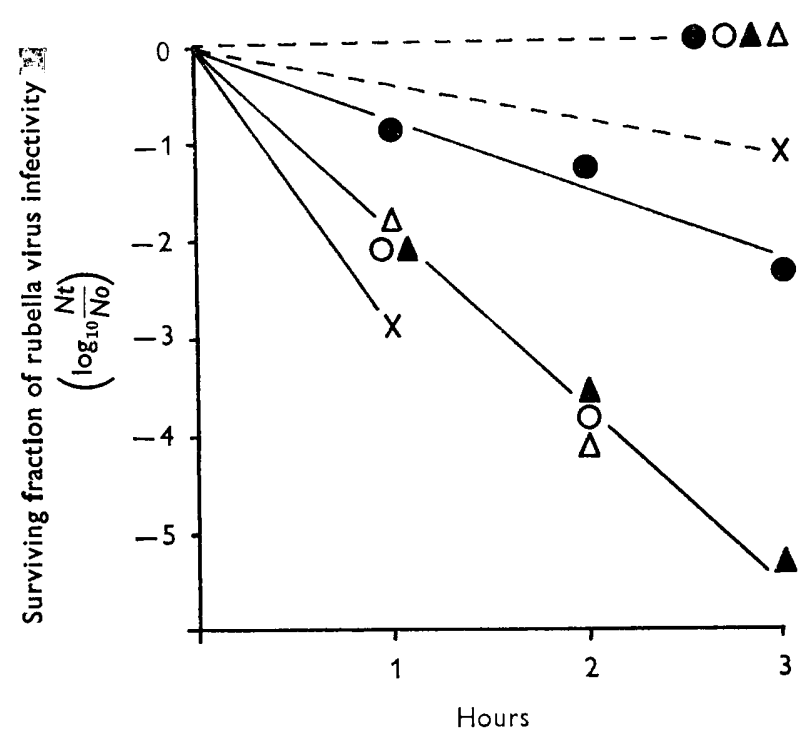

FIG. 1.-Rate of loss of infectivity of rubella virus suspensions exposed to light: $-=$ virus exposed to light; $--=$ virus held in darkness (dark controls); 0 =virus in tissue culture maintenance medium, $p \mathrm{H} \quad 7 \cdot 0-7 \cdot 2 ; 0=$ virus in PBS, $p \mathrm{H} \quad 7 \cdot 2 ; 0=$ virus in borate buffer, $p \mathrm{H} 8 \cdot 0 ; \triangle=$ virus in borate buffer, $p \mathrm{H} 10 \cdot 0 ; \times=$ virus in carbonate-bicarbonate buffer, $p \mathrm{H} 10 \cdot 0$.

it completely (table). Thus, PBS-suspensions of virus containing 2 per cent. kaolin-treated foetal calf serum lost only $10^{1.25}$ TCD50 of infectivity per ml

TABLE

Effect of kaolin-treated foetal calf serum and L-cysteine on rubella virus photosensitivity

\begin{tabular}{|c|c|c|c|c|}
\hline \multirow{2}{*}{$\begin{array}{c}\text { Serum } \\
\text { concentration } \\
\text { (per cent.) }\end{array}$} & \multirow{2}{*}{$\begin{array}{c}\text { Presence or } \\
\text { absence of } \\
\text { L-cysteine } \\
(1 \mathrm{mg} \text { per } \mathrm{ml})\end{array}$} & \multicolumn{3}{|c|}{$\begin{array}{c}\text { Infectivity }\left(\log _{10} \text { TCD50 per ml) of }\right. \\
\text { rubella virus suspension }\end{array}$} \\
\hline & & $\begin{array}{l}\text { before } \\
\text { irradiation }\end{array}$ & $\begin{array}{l}\text { after } 2 \text { hours' } \\
\text { irradiation }\end{array}$ & $\begin{array}{l}\text { after } 2 \mathrm{hr} \text { in } \\
\text { darkness }\end{array}$ \\
\hline $\begin{array}{r}0 \\
0 \\
2 \\
5 \\
10\end{array}$ & $\begin{array}{l}\overline{+} \\
\pm \\
\overline{-}\end{array}$ & $\begin{array}{l}5 \cdot 75 \\
5 \cdot 25 \\
5 \cdot 5 \\
5 \cdot 5 \\
5 \cdot 25\end{array}$ & $\begin{array}{l}2 \cdot 25 \\
5 \cdot 5 \\
4 \cdot 25 \\
4 \cdot 5 \\
4 \cdot 25\end{array}$ & $\begin{array}{l}5 \cdot 25 \\
5 \cdot 25 \\
5 \cdot 5 \\
5 \cdot 5 \\
5 \cdot 25\end{array}$ \\
\hline
\end{tabular}

after 2 hours' irradiation, compared with a loss of $10^{3.5}$ TCD50 per $\mathrm{ml}$ in serum-free suspensions. Higher concentrations of serum did not further reduce the photosensitivity of the virus in PBS. When PBS-suspensions of rubella virus were supplemented with L-cysteine, $1 \mathrm{mg}$ per $\mathrm{ml}$, there was no loss of infectivity, 
even after 2 hours' illumination, showing that, as in the case of other lightsensitive viruses, the photoinactivation mechanism is dependent on oxidising conditions (Cutchins and Dayhuff; Appleyard).

Tests were carried out to decide whether the photosensitivity of rubella virus is truly intrinsic or whether some of the tissue culture medium components were sensitising the virus to light during its growth. The stability of the HA on exposure to light indicated that any light-sensitising components were unlikely to be anionic in nature; photodynamic inactivation in the presence of anionic sensitisers acts mainly against protein (Turner and Kaplan, 1968). With cationic photosensitisers, the rate of inactivation of viruses increases with pH (Welsh and Adams, 1954; Yamamoto, 1956; Wallis and Melnick, 1964; Turner and Kaplan, 1965). An attempt was therefore made to detect such cationic agents by suspending rubella virus in PBS mixed with an equal volume

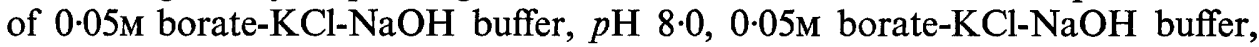
$p \mathrm{H} 10 \cdot 0$, or $0 \cdot 1 \mathrm{M}$ carbonate-bicarbonate buffer, $p \mathrm{H} 10 \cdot 0$. The suspensions were illuminated for $3 \mathrm{hr}$, together with corresponding dark controls. The rate of loss of virus infectivity in borate buffer at both $p \mathrm{H} 8.0$ and $p \mathrm{H} \mathrm{10.0}$

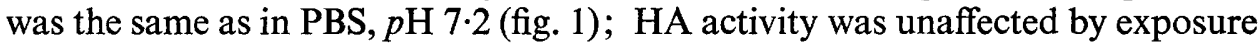
to light at these higher $p \mathrm{H}$ values. In the carbonate-bicarbonate buffer, $p \mathrm{H}$ 10.0 , the rate of inactivation was greater than in the borate buffer of the same $p \mathrm{H}$. However, this was due to the fact that the virus was unstable in carbonatebicarbonate buffer, shown by a significant fall in infectivity titre in the dark controls. These results suggested that rubella virus does, in fact, possess intrinsic photosensitivity.

\section{Photodynamic inactivation after sensitisation with proflavine}

Two methods of photosensitising rubella virus with proflavine were investigated and compared, namely, direct mixing of virus and dye and growing the virus in the presence of the dye.

Direct mixing with proflavine. Proflavine solution, $100 \mu \mathrm{g}$ per $\mathrm{ml}$, was added to a series of 4-ml amounts of stock rubella virus to give final concentrations of $0 \cdot 05,0 \cdot 1,0 \cdot 5,1 \cdot 0,5.0$ and $10.0 \mu \mathrm{g}$ per $\mathrm{ml}$. The $p \mathrm{H}$ of these proflavinecontaining virus suspensions was $7 \cdot 0-7 \cdot 1$. The mixtures were at once exposed to light together with dark controls.

In two experiments, the rate of photodynamic inactivation of the virus increased progressively with the concentration of proflavine, and the survival curves, for all the concentrations, were linear with respect to time of exposure to light (fig. 2). With $0 \cdot 1,0.5$ and $10.0 \mu \mathrm{g}$ per $\mathrm{ml}$ of dye there was complete loss of infectivity after 90,40 and $20 \mathrm{~min}$. respectively. The same dye-virus mixtures in the dark showed no loss of infectivity. Calculation of the inactivation rate constants showed that the rate of inactivation of rubella virus reached a maximum at about $5.0 \mu \mathrm{g}$ per $\mathrm{ml}$ of the dye (fig. 3). Illumination in the presence of 0.05 to $1.0 \mu \mathrm{g}$ per $\mathrm{ml}$ of proflavine had no significant effect on the HA titre of the virus suspensions, even after 90 min., but with higher concentrations, 5.0 and 10.0 $\mu \mathrm{g}$ per ml, HA activity was destroyed after 40-60 min. 


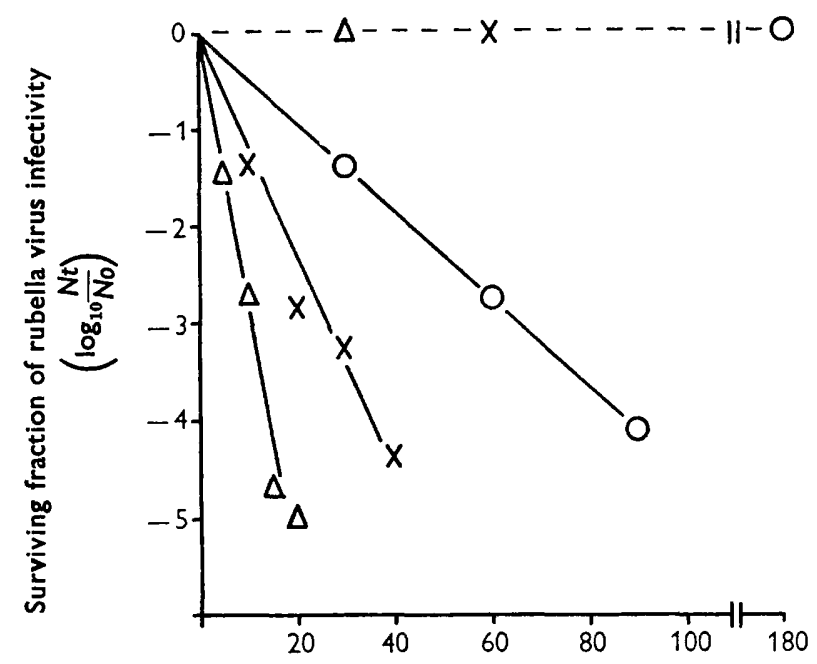

Minutes

FIG. 2.-Rate of loss of infectivity of rubella virus suspensions directly sensitised with various concentrations of proflavine, when exposed to light: $--=$ virus exposed to light; $--=$ virus held in darkness (dark controls); $\mathrm{O}=$ suspensions containing $0.1 \mu \mathrm{g}$ per ml of proflavine; $X=$ suspensions containing $0.5 \mu \mathrm{g}$ per $\mathrm{ml}$ of proflavine; $\Delta=$ suspensions containing $10 \mu \mathrm{g}$ per $\mathrm{ml}$ of proflavine.

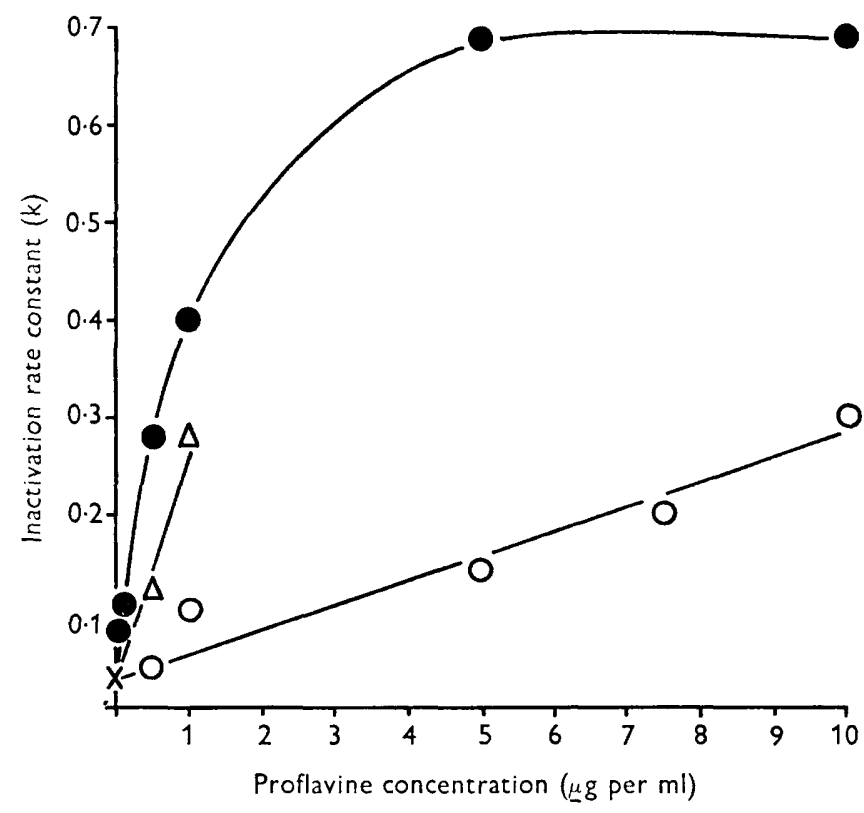

FIG. 3.-Efficiency of photodynamic inactivation of rubella virus after sensitisation to light by direct mixing with proflavine or by growth in proflavine-treated tissue cultures: $\times=$ virus in maintenance medium without proflavine; - = virus sensitised by direct mixing with proflavine; $\triangle=$ virus grown in tissue cultures containing proflavine in the maintenance medium; $O=$ virus grown in tissue cultures pre-treated with proflavine. 
As with the intrinsic photosensitivity of the virus, photodynamic inactivation in the presence of proflavine was dependent on oxidising conditions, since it was completely inhibited by L-cysteine; a virus suspension containing $0.5 \mu \mathrm{g}$ per $\mathrm{ml}$ of proflavine and $5 \mathrm{mg}$ per $\mathrm{ml}$ of L-cysteine showed no significant loss of infectivity after exposure to light for $30 \mathrm{~min}$. The attachment of the proflavine to rubella virus was also completely reversible, as is the case with most other basic dye-virus complexes (Sprecher-Goldberger, 1965; Fukunaga et al.; Content and Cogniaux-Leclerc, 1968). A rubella virus suspension containing $10 \mu \mathrm{g}$ per $\mathrm{ml}$ of proflavine was extracted with Dowex 50W cation-exchange resin and then exposed to light for $30 \mathrm{~min}$; t there was now no significant loss of infectivity.

The possibility was investigated that the loss of HA activity in the presence of the higher concentrations of proflavine was due to photochemical modification of tissue culture components with resulting formation of non-specific inhibitors of HA, rather than to direct photodynamic inactivation of surface antigens of the virus particle. However, illumination of virus suspended in PBS, instead of maintenance medium, containing $10 \mu \mathrm{g}$ per $\mathrm{ml}$ of proflavine also caused complete destruction of HA activity, and there was no recovery of activity after attempts to remove possible non-specific inhibitors by extracting the inactivated virus preparations with Tween 80-ether. The supernatants of non-infected BHK21 cell cultures were also irradiated for $1 \mathrm{hr}$ in the presence of proflavine and tested for $\mathrm{HI}$ activity against active rubella virus; none was found. It is, therefore, unlikely, that the loss of HA activity after illumination in the presence of higher concentrations of proflavine is due to the formation of non-specific inhibitors in the suspending medium.

Growing rubella virus in the presence of proflavine. Two methods of sensitising rubella virus during growth in tissue culture were investigated. The first was to grow the virus in the continuous presence of the dye. Monolayers of BHK21 cells were grown in 8-oz. medical flat bottles. The supernatant fluids were discarded and replaced with $4 \mathrm{ml}$ amounts of rubella virus suspension, giving an inoculum dose of 0.1 TCD50 per cell. After a 2-hr period of adsorption at $33^{\circ} \mathrm{C}$ in the dark, with occasional gentle rocking, the cell sheets were washed with $12 \mathrm{ml}$ of Hanks' BSS and refed with maintenance medium containing either $0.5 \mu \mathrm{g}$ per $\mathrm{ml}$ or $1.0 \mu \mathrm{g}$ per $\mathrm{ml}$ of proflavine. Earlier tests had already shown that higher concentrations of proflavine were toxic and caused extensive or complete destruction of the cell sheets within 2 to 3 days. The bottles were returned to the incubator in the dark and again refed $24 \mathrm{hr}$ later with fresh maintenance medium containing the same concentrations of dye. After a further 2 days the pooled supernatants from paired bottles containing the same concentrations of proflavine were centrifuged at 4000 r.p.m. for $10 \mathrm{~min}$. to remove any cell debris and aliquots were either exposed to light or used as dark controls. Specimens were removed at 10-min. intervals during the period of illumination for measurement of infectivity and HA.

The second method of proflavine sensitisation involved treatment only of the tissue cultures with dye for a short period before virus inoculation. Freshly grown sheets of BHK21 cells were refed with $12 \mathrm{ml}$ of pre-warmed 
maintenance medium containing proflavine in concentrations ranging from 0.5 to $10.0 \mu \mathrm{g}$ per ml. Earlier tests had shown that pre-treatment of BHK21 cells with $5 \mu \mathrm{g}$ per $\mathrm{ml}$ of proflavine did not lead to obvious damage of the cells during their subsequent incubation, in the absence of the dye, for 3 days; with $10 \mu \mathrm{g}$ per $\mathrm{ml}$ there was rounding of a small number of cells after 3 days. The proflavine-treated bottles were incubated for $2 \mathrm{hr}$ at $33^{\circ} \mathrm{C}$ in the dark and the cell sheets were then washed three times with $12 \mathrm{ml}$ amounts of Hanks' BSS and inoculated with virus at a dose of 0.1 TCD50 per cell. Incubation was continued for a further $2 \mathrm{hr}$ to allow virus adsorption, after which time the cells were washed again three times and finally refed with maintenance medium without proflavine and returned to the incubator at $33^{\circ} \mathrm{C}$ in the dark. Three days later the pooled supernatants from paired bottles which had been pretreated with the same concentrations of proflavine were centrifuged at 4000 r.p.m. for $10 \mathrm{~min}$. and exposed to light. Specimens were taken for infectivity and HA tests during the period of illumination, as described above.

By both methods of sensitisation, the rate of photodynamic inactivation of virus infectivity increased proportionately with the dye concentration and was linear with respect to time; dark controls showed no significant reduction in infectivity. The HA activity of all the virus suspensions, grown by both methods, was unchanged even after 60 minutes' exposure to light. However, comparison of the inactivation rate constants showed that neither method was as efficient for photosensitisation of the virus as direct mixing with dye (fig. 3).

Photosensitised virus obtained from BHK21 cell cultures pretreated with $10 \mu \mathrm{g}$ per $\mathrm{ml}$ of proflavine could be completely desensitised by extraction with resin, indicating that the dye-virus complex formed intracellularly is as reversible as that formed by direct mixing.

The effect of alkaline $\mathrm{pH}$ on photodynamic inactivation of proflavine-sensitised virus. The rate of photodynamic inactivation of viruses in the presence of cationic dyes increases with $\mathrm{pH}$ (Welsh and Adams; Yamamoto; Wallis and Melnick, 1964; Turner and Kaplan, 1965). This effect was examined with rubella virus and proflavine. Stock rubella virus suspensions were diluted

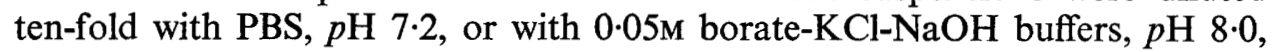
9.0 or 10.0 , and proflavine was added to give a concentration of $0.5 \mu \mathrm{g}$ per ml. The mixtures were then exposed to light. The rate of inactivation of virus infectivity increased strikingly with $p \mathrm{H}$ to a maximum at about $p \mathrm{H} 9.0(\mathrm{k}=$ 0.9 min. $^{-1}$ ) (fig. 4). However at $p \mathrm{H} 9.0$ there was no loss of $\mathrm{HA}$ activity, even after $60 \mathrm{~min}$. Dark controls showed no loss of either infectivity or HA activity at $p \mathrm{H} 9 \cdot 0$.

Residual infectivity and antigenic activity of photodynamically inactivated rubella virus. Direct mixing of rubella virus with $0.5 \mu \mathrm{g}$ per $\mathrm{ml}$ of proflavine, at $p \mathrm{H} 9 \cdot 0$, appeared to provide near optimal conditions for photodynamic inactivation of infectivity without loss of HA activity. Further tests were carried out to determine whether the light irradiation, under these conditions, totally destroyed the infectivity of the virus suspension or whether occasional virus particles survived, perhaps protected inside small aggregates.

A fresh batch of rubella virus was prepared in BHK21 cells in roller bottles; 
this had an infectivity titre of 106.25 TCD50 per $\mathrm{ml}$ and an HA titre of 32 units per $0.025 \mathrm{ml}$. Two $\mathrm{ml}$ portions were diluted with equal volumes of borate

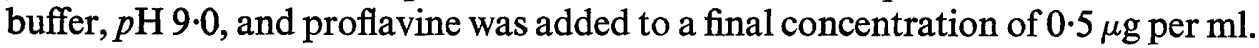

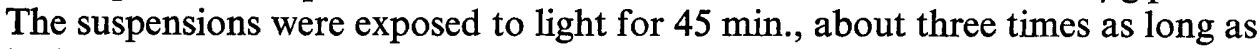
is theoretically required for complete inactivation of this concentration of virus based on an inactivation rate constant of $0.9 \mathrm{~min}^{-1}$. After irradiation, the virus suspensions were extracted with cation-exchange resin to remove both excess and reversibly bound dye.

The final products showed no loss of original HA activity. Residual infectivity was investigated by inoculating the bulk of each batch of irradiated virus suspension, in $0 \cdot 1 \mathrm{ml}$ amounts, into 30 tube-cultures of RK13 cells. No

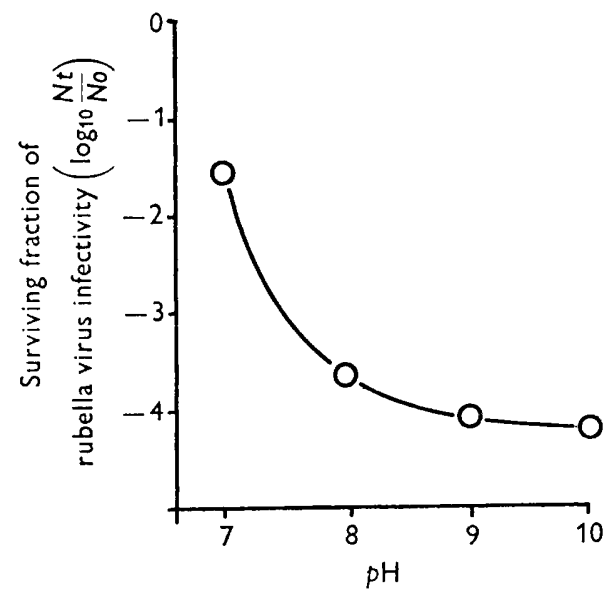

FIG. 4.-Effect of $p \mathrm{H}$ on the photodynamic inactivation of rubella virus mixed with $0.5 \mu \mathrm{g}$ per ml of proflavine.

cytopathic effects occurred in any of the tubes over an observation period of 14 days. The supernatants and cells from half the tubes were then harvested and subcultured into fresh RK13 tubes. These also showed no cytopathic effects after 14 days. There was, therefore, less than 1 TCD50 of virus in $3.0 \mathrm{ml}$ of irradiated vaccine.

Further tests were undertaken in four young adult cynomolgus monkeys which had no rubella $\mathrm{HI}$ antibodies. Two of them were given $3 \mathrm{ml}$ of the inactivated virus preparation intravenously. The others, kept in separate rooms under strict barrier-nursing precautions, were given intravenously $1.5 \mathrm{ml}$ of untreated, infectious virus from the same batch that was used to prepare the vaccine. At weekly intervals for the next $18 \mathrm{wk}$, the monkeys were weighed, their rectal temperature was taken and throat swabs and blood specimens were collected. Throughout the entire experiment there was no significant change in the weight or body temperature of the four animals. Rubella virus was not isolated from any of the throat swabs, despite three serial passages in RK13 cells.

Neither of the monkeys given the vaccine preparation had detectable J. MED. MICROBIOL.-VOL. 5 (1972) 
amounts of HI antibodies after $4 \mathrm{wk}$. However, a booster dose of $3 \mathrm{ml}$ of vaccine given at that time produced HI antibodies to a titre of 256 in one of the animals 3-4 wk later; antibodies were still present, at a titre of 32, $14 \mathrm{wk}$ after the booster dose. CF antibodies were not found. On the other hand, both monkeys given live virus had developed HI antibodies (titres 128-256) 2-3 wk after the initial dose. These titres increased four- to eight-fold after a booster dose of live virus and CF antibodies also then appeared (titres 16-64). The HI antibody titres gradually fell but titres of 128-256 were still present $14 \mathrm{wk}$ after the booster injection. The CF antibody titres stayed high for 3-4 wk and then slowly declined to become undetectable after a further 6-8 wk.

\section{Discussion}

Intrinsic photosensitivity is a property common to many enveloped viruses, including myxoviruses and arboviruses (Skinner and Bradish, 1954; Cutchins and Dayhuff, 1962; Wallis and Melnick, 1964; Nemo and Cutchins, 1966; Appleyard, 1967; Wallis, Trulock and Melnick, 1969). The mechanism of photoinactivation of rubella virus, in the absence of added photosensitisers, is similar to that described for these other viruses. Loss of infectivity occurs proportionally with time of illumination, is oxygen-dependent and is markedly reduced in the presence of serum. Whether the photosensitivity of enveloped viruses is truly intrinsic or dependent on some photosensitising component present in the host cell or in the tissue culture medium is still uncertain (Wallis and Melnick, 1965; Appleyard). Eagle's medium contains various vitamin B fractions, such as riboflavin, which might act as photosensitisers. However, in the case of rubella virus, absence of any increase in the rate of photoinactivation under more alkaline conditions failed to support this possibility. The fact that HA activity was not significantly reduced over periods of illumination which abolished infectivity suggested that, in rubella virus too, the primary target of the photodynamic reaction is the viral nucleic acid rather than viral protein.

As with myxoviruses and arboviruses (Perdrau and Todd, 1933a; Hiatt, 1960; Tomita and Prince, 1963; Sprecher-Goldberger, 1965; Wallis and Melnick, 1965; Fukunaga et al., 1967; Content and Cogniaux-Leclerc, 1968), the photosensitivity of rubella virus was markedly enhanced after mixing it directly with proflavine. Only picornaviruses seem to be refractory to this procedure (Crowther and Melnick, 1961; Hackett, 1962; Schaffer, 1962; Wilson and Cooper, 1963). Direct mixing proved to be more efficient for photosensitisation than growing the virus in tissue culture in the presence of the dye. Proflavine readily enters cells and its presence during replication of the virus might have been expected to facilitate its attachment to the viral ribonucleic acid while this was being manufactured and before its encapsidation by protein. The lower efficiency actually found may well have been due to binding of the proflavine to cell components, so that it was less easily available to the viral nucleic acid. The use of increased concentrations of proflavine to overcome this difficulty was limited by its toxicity for the cells. 
With all three methods of proflavine sensitisation, the infectivity of rubella virus suspensions decreased exponentially with the duration of illumination. Similar findings have been reported for other viruses photosensitised with basic dyes (Oster and McLaren, 1950; Hiatt; Tomita and Prince; Turner and Kaplan, 1965; Frank and Foster, 1967; Fukunaga et al.). The rate of photodynamic inactivation also increased with the concentration of proflavine. When virus was mixed directly with dye the rate increased with proflavine concentration up to a maximum at about $5 \mu \mathrm{g}$ per $\mathrm{ml}$. This concentration of dye, however, produced appreciable loss of HA activity. This was not entirely unexpected since it is known that basic photosensitising dyes catalyse the photooxidation of both proteins (Weil, James and Buchert, 1953; Weil and Seibles, 1955) and amino acids (Weil, Gordon and Buchert, 1951; Sluyterman, 1962; Harrison, Raabe and Brummett, 1968). Thus, Wallis, Sakurada and Melnick (1963) demonstrated that purified haemagglutinin of influenza A virus is destroyed by light in the presence of toluidine blue, and Turner and Kaplan (1968) showed that the immunogenicity of vaccinia virus decreases upon prolonged exposure to light in the presence of methylene blue. Fortunately, this effect could be countered by means of $p \mathrm{H}$. In common with other basic dyevirus systems, the photodynamic-inactivation rate of proflavine-sensitised rubella virus increases with $p \mathrm{H}$. The rate of inactivation in the presence of $0.5 \mu \mathrm{g} \mathrm{per} \mathrm{ml}$ of the dye at $p \mathrm{H} \mathrm{9.0} \mathrm{was} \mathrm{considerably} \mathrm{greater} \mathrm{than} \mathrm{with} 5 \mu \mathrm{g}$ per ml at $p \mathrm{H} 7 \cdot 0$ $7 \cdot 1$, and there was no detectable loss of $\mathrm{HA}$ activity. At high $p \mathrm{H}$ levels $(8 \cdot 0-10 \cdot 0)$ the efficiency of inactivation is actually greater than the theoretical maximum for the virus at $p \mathrm{H} \mathrm{7.0.} \mathrm{This} \mathrm{may} \mathrm{be} \mathrm{due} \mathrm{to} \mathrm{irreversible} \mathrm{binding} \mathrm{of}$ proflavine to rubella virus at these higher $p \mathrm{H}$ levels, a phenomenon which has been found to occur with some other dye-virus systems (Wallis and Melnick, 1964; Turner and Kaplan, 1965).

The loss of infectivity, under optimal conditions, appeared to be complete, although the results did not entirely preclude the persistence of a very low level of infectious virus at the end of the exponential phase of the inactivation curve. The union of proflavine with rubella virus appears to be completely reversible by extraction with cation-exchange resin, before exposing to light. However, whether some proflavine remains firmly bound to virus after light inactivation, particularly at high $p \mathrm{H}$, requires further investigation.

Attempts to prepare inactivated rubella virus vaccines by treatment with formalin or ethylene oxide, both of which denature protein, have met with little success (Sever, Schiff and Huebner, 1963; Frankel, 1964; Meyer and Parkman, 1967). Photodynamic inactivation, in the presence of sensitising, cationic dyes, is a relatively simple and yet efficient technique which acts by preferentially damaging viral nucleic acid, leaving surface protein immunogenicity virtually intact. Such vaccines prepared against viruses other than rubella virus have given better antibody responses than formolised vaccines (Wallis, Sakurada and Melnick; Wallis, Scheiris and Melnick, 1967). The preparation made by illuminating rubella virus directly mixed with proflavine at $p \mathrm{H} 9.0$ stimulated the formation of rubella HI antibodies in monkeys, although it was considerably less potent than the same dose of live virus. Obviously, the amount of 
antigenic material in a killed vaccine is critical and the use of more sensitive tissue cultures and suitable concentration techniques should provide more effective preparations.

\section{SUMMARY}

Rubella virus possesses inherent photosensitivity and slowly loses infectivity when exposed to light. Sensitisation with proflavine markedly increases the rate of photoinactivation, and loss of infectivity, without loss of haemagglutinin

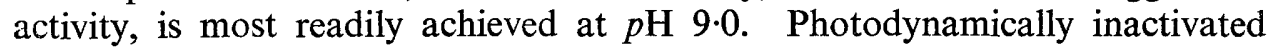
rubella virus stimulates $\mathrm{HI}$ antibody formation in monkeys.

This work was carried out with the aid of generous grants from the Mental Health Research Fund.

\section{REFERENCES}

Appleyard, G. 1967. The photosensitivity of Semliki Forest and other viruses. J. Gen. Virol., 1, 143.

BECK, E. S. 1969. Review of studies with inactivated rubella virus. Amer. J. Dis. Child., 118, 328.

BORGEN, H. C., AND ESPENSEN, L. 1970. Immunizing effect of photoinactivated pseudorabies virus. Zentbl. Bakt. ParasitKde, I. Abt. Orig., 214, 13.

Chessin, M. 1960. Photodynamic inactivation of infectious nucleic acid. Science, N.Y., 132, 1840.

Content, J., ANd COGNiAuX-LeClerc, JACQueline 1968. Comparison of the in vitro action of ethidium chloride on animal viruses with that of other photodyes. J. Gen. Virol., $3,63$.

Crawford, J. G., and Dayhuff, T. R. 1968. Hog cholera: preparation of hog cholera immunogen from photodynamically inactivated virus. Amer. J. Vet. Res., 29, 1741.

Crawford, J. G., Dayhuff, T. R., AND White, E. A. 1968. Hog cholera: safety and protection studies with photodynamically inactivated hog cholera virus. Amer.J. Vet. Res., 29, 1749.

Crawford, J. G., White, E. A., AND Dayhuff, T. R. 1968. Hog cholera: response of pigs vaccinated under field conditions with photodynamically inactivated hog cholera vaccine of tissue culture origin. Amer. J. Vet. Res., 29, 1761.

Crowther, D., AND Melnick, J. L. 1961. The incorporation of neutral red and acridine orange into developing poliovirus particles making them photosensitive. Virology, $14,11$.

Cutchins, E. C., AND Dayhuff, T. R. 1962. Photoinactivation of measles virus. Virology, 17,420 .

Dempsey, T. F., AND MeYer, V. 1934. Canine distemper vaccine. Two experiments with vaccine prepared by photodynamic inactivation of the virus with methylene blue. J. Comp. Path. Ther., 47, 197.

Frank, G. H., AND Foster, J. W. 1967. Photodynamic inactivation of Newcastle disease virus with acridine orange. Appl. Microbiol., 15, 1452.

Frankel, J. W. 1964. Neutralizing antibody responses of guinea-pigs to inactivated rubella virus vaccine. Nature, Lond., 204, 655.

Fukunaga, T., Ishikawa, N., Igarashi, A., AND FukaI, K. 1967. Photodynamic inactivation of Japanese encephalitis virus. Biken J., 10, 1.

HACKETT, A. J. 1962. The photodynamic effects of acridine orange on an RNA virus (vesicular exanthema). Photochem. Photobiol., 1, 147.

HarRison, A. P., RaABe, V. A., AND BRUMmetT, G. H. 1968. Detection of in vivo protein photooxidation by means of tritium loss from the histidine moieties. Proc. Soc. Exp. Biol. Med., 127, 538. 
Hiatr, C. W. 1960. Photodynamic inactivation of viruses. Trans. N.Y. Acad. Sci., 23, 66.

Hilleman, M. R., BuYnaK, E. B., Weibel, R. E., AND Stokes, J., JR 1968. Live, attentuated rubella-virus vaccine. New Engl. J. Med., 279, 300.

KAPLAN, C. 1969. Immunization against smallpox. Br. Med. Bull., 25, 131.

Meyer, H. M., JR, AND Parkman, P. D. 1967. Rubella: epidemiology, virology and immunology. III. The immunology of rubella. Amer. J. Med. Sci., 253, 364.

Nemo, G. J., AND Cutchins, E. C. 1966. Effects of visible light on canine distemper virus. J. Bact., 91, 798.

OSTER, G., AND MCLAREN, A. D. 1950. The ultraviolet light and photosensitized inactivation of tobacco mosaic virus. J. Gen. Physiol., 33, 215.

Perdrau, J. R., AND TodD, C. R. 1933a. The photodynamic action of methylene blue on certain viruses. Proc. Roy. Soc. B, 112, 288.

Perdrau, J. R., AND Todd, C. $1933 b$. Canine distemper. The high antigenic value of the virus after photodynamic inactivation by methylene blue. J. Comp. Path. Ther., 46, 78.

ReEd, L. J., AND MuenCH, H. 1938. A simple method of estimating fifty per cent. endpoints. Amer. J. Hyg., 27, 493.

SCHAFFER, F. L. 1962. Binding of proflavine by and photoinactivation of poliovirus propagated in the presence of the dye. Virology, 18, 412.

Schmidt, N. J., Lennette, E. H., Gee, P. S., And Dennis, J. 1968. Physical and immunologic properties of rubella antigens. J. Immun., 100,851.

SeVER, J. L., SChIFF, G. M., AND HuEbneR, R. J. 1963. Inactivated rubella virus vaccine. J. Lab. Clin. Med., 62, 1015.

SKINNER, H. H., AND BRADISH, C. J. 1954. Exposure to light as a source of error in the estimation of the infectivity of virus suspensions. J. Gen. Microbiol., 10, 377.

Sluyterman, L. A. Ae. 1962. Photo-oxidation, sensitized by proflavine, of a number of protein constituents. Biochim. biophys. acta, 60, 557.

SPRECHER-GoldBerGeR, S. 1965. Photosensitization of RNA viruses by ethidium chloride. Acta virol., Prague, 9, 385.

Stewart, G. L., Parkman, P. D., Hopps, H. E., Douglas, R. D., Hamilton, J. P., and MeYer, H. M. 1967. Rubella-virus hemagglutination-inhibition test. New Engl.J. Med., 276, 554.

Tomita, T., AND Prince, A. M. 1963. Photodynamic inactivation of arbor viruses by neutral red and visible light. Proc. Soc. Exp. Biol. Med., 112, 887.

TURNER, G. S., AND KAPLAN, C. 1965 . Observations on photodynamic inactivation of vaccinia virus and its effect on immunogenicity. J. Hyg., Camb., 63, 395.

TURNeR, G. S., AND KAPLAN, C. 1968. Photoinactivation of vaccinia virus with rose bengal. J. Gen. Virol., 3, 433.

Wallis, C., AND MeLNICK, J. L. 1964. Irreversible photosensitization of viruses. Virology, 23, 520.

Wallis, C., AND MelNiCK, J. L. 1965. Photodynamic inactivation of animal viruses: a review. Photochem. Photobiol., 4, 159.

Wallis, C., SAKurada, N., AND MELnick, J. L. 1963. Influenza vaccine prepared by photodynamic inactivation of virus. J. Immun., 91, 677.

Wallis, C., Scheiris, Charlotte, ANd Melnick, J. L. 1967. Photodynamically inactivated vaccines prepared by growing viruses in cells containing neutral red. J. Immun., 99, 1134.

Wallis, C., Trulock, S., AND Melnick, J. L. 1969. Inherent photosensitivity of herpes virus and other enveloped viruses. J. Gen. Virol., $5,53$.

WeIL, L., Gordon, W. G., AND BUCherT, A. R. 1951. Photoöxidation of amino acids in the presence of methylene blue. Archs Biochem. Biophys., 33, 90.

WeIL, L., JAMES, S., AND BUCHERT, A. R. 1953. Photooxidation of crystalline chymotrypsin in the presence of methylene blue. Archs Biochem. Biophys., 46, 266.

WeIr, L., AND SeIBLES, T. S. 1955. Photooxidation of crystalline ribonuclease in the presence of methylene blue. Archs Biochem. Biophys., 54, 368. 
Welsh, J. N., ANd Adams, M. H. 1954. Photodynamic inactivation of bacteriophage. J. Bact., 68, 122.

WILSON, J. N., AND COOPER, P. D. 1963. Aspects of the growth of poliovirus as revealed by the photodynamic effects of neutral red and acridine orange. Virology, 21, 135.

Yamamoto, N. 1956. Photodynamic action on bacteriophage. I. The relation between the chemical structure and the photodynamic activity of various dyes. Virus, 6, 510. 